\title{
人間ドック受診者における泌尿器がん（腎がん・膀胱がん・前立腺がん）罹患率および リスク因子に関する検討
}

\author{
1) 聖隷予防検診センター, ${ }^{2)}$ 聖隷健康診断センター, ${ }^{3)}$ 浜松医科大学泌尿器科 \\ 野畑 俊介 ${ }^{13)}$ 木内正太郎 ${ }^{11} \quad$ 渡辺めぐみ ${ }^{11}$ \\ 森 厚嘉 ${ }^{11}$ 武藤 繁貴 ${ }^{22}$ 三宅 秀明 ${ }^{32}$
}

要旨:

（目的）人間ドックの問診および結果から泌尿器がん（腎がん，膀胱がん，前立腺がん）の罹患率掞よびリ スク因子を検討する。

(対象と方法) 2006 年 4 月から 2008 年 3 月の間に人間ドックを受診した 48,454 名を対象とした．その後対 象者が泌尿器がんに新たに診断されたか否かを調查し, 各泌尿器がんの罹患率および罹患と相関するリスク 因子を検討した，検討因子は，性別，年齢，総契煙年数，body mass index，飲酒， 20 歳時より体重が $10 \mathrm{~kg}$ 以上増加, ストレスの蓄積, 十分な睡眠, 十分な乳製品摂取, 高血圧, 糖尿病および脂質異常症とした.

（結果）腎がん，膀胱がんおよび前立腺がんの罹患を，それぞれ 45,47 および 215 例に認め，罹患率はそれ ぞれ $0.093,0.097$ および $0.721 \%$ であった， 単変量解析で有意な相関を示したのは, 腎がんでは男性, 高龄者, BMI 高值, 飲酒, 体重 $10 \mathrm{~kg}$ 以上の増加および高血圧, 膀胱がんでは男性, 高齢者, 総揳煙年数および飲酒, 前立腺がんでは高齢者, 総契煙年数, 体重 $10 \mathrm{~kg}$ 以上の増加, ストレス蓄積者および脂質異常症であった，次 いで多変量解析を施行し, 腎がんでは高齢者, 膀胱がんでは男性および高齢者, 前立腺がんでは高齢者および 脂質異常症で有意な相関を示した.

（結論）高齢者はいずれの泌尿器がんにおいても共通してその罹患と独立した相関を示した.

キーワード：人間ドック, リスク因子, 泌尿器がん

（日泌尿会誌１11(4)：114～119, 2020）

\section{緒言}

国立がん研究センターがん情報サービスによる「がん 登録・統計」 ${ }^{1)}$ による, 本邦における 2014 年の部位別 罹患数は, 男性では胃がん (86,656 名), 肺がん（76,879 名), 大腸がん $(76,718$ 名)に次いで, 前立腺がんは 73,764 名で第 4 位，腎がんなど（腎孟尿管を含む）は 16,781 名で第 8 位, 膀胱がんは 15,486 名で第 10 位となってい る。一方，女性においては腎がんなど(腎孟尿管を含む) は 7,900 名で第 14 位, 膀胱がんは 5,109 名で第 16 位と報 告されている.特に前立腺がんに関しては急速な高齢化, PSA 検診の普及および食生活の欧米化などにより増加 傾向が続いており, 2015 年には罹患数が第 1 位となって いる. がん診療においては, 早期発見の促進は依然とし て重要な課題であるが, リスク因子を同定しそれに基づ いて生活指導を行うことにより罹患数減少を実現する試 みも求められている. 近年の疫学的研究においては, 泌 尿器がんの罹患とタバコ, 飲酒およびメタボリックシン
ドロームなどとの相関が報告されているが，本邦におけ る検討は限られており, その詳細な実態は明らかではな い. 今回泌尿器がんのリスク因子の同定を目的として, 検診施設における人間ドック受診者を対象に, 主要な泌 尿器がんの罹患率を解析し, 各泌尿器がんの罹患と種々 の因子との相関を検討したので報告する.

\section{対象・方法}

2006 年 4 月から 2008 年 3 月までの 2 年間に聖隷予防 検診センターおよび聖隷健康診断センターで人間ドック を受診した症例中, 2006 年以前に上記のいずれかの泌尿 器がんに罹患していた症例を除いた 48,454 名を対象と した.

人間ドックの受診以後, 対象者が泌尿器がん(腎がん, 膀胱がん，前立腺がん）に新たに罹患したか否かを 2017 年 3 月までの 9 年間調査した. 泌尿器がん罹患の調査方 法であるが，上記 2 センターでは受診者のがんが判明次 第，すべて共通のシステムに登録している．把握する方

受付日：2020 年 4 月 19 日, 受理日：2020 年 5 月 26 日

野畑俊介：聖隷予防検診センター〔テ433-8558 静岡県浜松市北区三方原町 3453-1〕

E-mail: nobasyun912@nifty.com

(C) 2020 The Japanese Urological Association 
表 1 全受診者および各種がんの背景

$\mathrm{IQR}$ : inter-quartile range

\begin{tabular}{|c|c|c|c|c|}
\hline & $\begin{array}{c}\text { 全受診者 } \\
N=48,454 \text { 名 }\end{array}$ & $\begin{array}{c}\text { 腎がん } \\
\mathrm{N}=45 \text { 名 } \\
(0.093 \%)\end{array}$ & $\begin{array}{l}\text { 膀胱がん } \\
\mathrm{N}=47 \text { 名 } \\
(0.097 \%)\end{array}$ & $\begin{array}{c}\text { 前立腺がん } \\
\mathrm{N}=215 \text { 名 } \\
(0.721 \%)\end{array}$ \\
\hline $\begin{array}{l}\text { 年齢 } \\
\text { (median (IQR)) }\end{array}$ & $52(44-59)$ & $59(53-66)$ & $58(53-67)$ & $66(62-71)$ \\
\hline 性（男性の割合） & 29,978 名 $(61.9 \%)$ & 35 名（77.8\%） & 43 名（91.5\%） & - \\
\hline $\begin{array}{l}\mathrm{BMI}\left(\mathrm{kg} / \mathrm{m}^{2}\right) \\
(\mathrm{mean} \pm \mathrm{SD})\end{array}$ & $22.7 \pm 3.1$ & $23.9 \pm 2.8$ & $23.5 \pm 2.5$ & $23.0 \pm 2.6$ \\
\hline $\begin{array}{l}\text { 罹患までの年数 } \\
\text { (median (IQR)) }\end{array}$ & - & $3(0-6)$ & $4(0-7)$ & $6(3-8)$ \\
\hline $\begin{array}{l}\text { 総喫煙年数 } \\
\text { (median }(\mathrm{IQR}))\end{array}$ & $0(0-20)$ & $10(0-25)$ & $21 \quad(2-30)$ & $20(0-34)$ \\
\hline 飲酒者（\%） & 26,179 名 $(54.0 \%)$ & 32 名（71.1\%） & 34 名（72.3\%） & 152 名 $(70.7 \%)$ \\
\hline 高血圧（\%） & 10,370 名 $(21.4 \%)$ & 18 名 (40.0\%) & 13 名 (27.7\%) & 65 名 $(30.2 \%)$ \\
\hline 糖尿病（\%） & 3,390 名（7.0\%） & 4 名（8.9\%） & 6 名 (12.8\%) & 21 名（9.8\%） \\
\hline 脂質異常症（\%） & 22,752 名 $(47.0 \%)$ & 24 名（53.3\%） & 26 名（55.3\%） & 128 名（59.5\%） \\
\hline
\end{tabular}

法としては，まず人間ドックを含むすべての健診からが んの有無の精查目的で紹介状を作成した場合, その紹介 した施設からの返事でがんの有無を確認する。またその 返事では詳細が不明な場合は後日紹介先に追跡依頼を行 いがんの有無を把握している。ささらに翌年以降の人間 ドックを含むすべての健診受診の際に，必ず問診にてす べてのがんの罹患の有無を確認している。これらの方法 で新たながんが判明次第システムに登録している。今回 その登録されたデータから 9 年間の泌尿器がん罹患の有 無を確認し, 各泌尿器がんの罹患の有無で 2 群に分けリ スク因子との相関を検討した。

検討因子は，2006 あるいは 2007 年の人間ドック受診 時の性別, 年齢, 総喫煙年数, body mass index (BMI), 飲酒の有無, 20 歳時より体重が $10 \mathrm{~kg}$ 以上増加の有無, 又 トレスの蓄積の有無，十分な睡眠の有無，十分な乳製品 摂取の有無, 高血圧の有無, 糖尿病の有無抒よび脂質異 常症の有無とした，総喫煙年数, 飲酒の有無, 20 歳時よ り体重が $10 \mathrm{~kg}$ 以上増加の有無, ストレスの蓄積の有無, 十分な睡眠の有無抢よび十分な乳製品の摂取の有無は, 問診結果に基づいて判断したが, 飲酒の有無に関しては, 週 1 日以上の飲酒習慣の有無を判断基準とした，血圧に 関しては収縮期血圧 $\geqq 140 \mathrm{mmHg}$ あるいは拡張期血圧 $\geqq$ $90 \mathrm{mmHg}$ を満たす症例, もしくは人間ドック受診時まで に他院で高血圧と診断されている症例を高血圧とした。 血糖については，空腹時血糖值 $\geqq 126 \mathrm{mg} / \mathrm{dL}$ に該当する 症例もしくは人間ドック受診時までに他院で糖尿病と診 断されている症例を糖尿病とした。脂質は LDL コレス テロール $\geqq 140 \mathrm{mg} / \mathrm{dL}, \mathrm{HDL}$ コレステロール $<40 \mathrm{mg} / \mathrm{dL}$ あるいはトリグリセライド $(\mathrm{TG}) \geqq 150 \mathrm{mg} / \mathrm{dL}$ を満たす 症例もしくは人間ドック受診時までに他院で脂質異常症 と診断されている症例を脂質異常症とした。

各泌尿器がんの罹患の有無に及ぼす各因子の影響を口 ジスティック回帰分析による単変量解析で評価し, 有意 差を認めた因子を同様に多変量解析に供した，統計処理
には BellCurve エクセル統計 for Windows を使用し，有 意水準は危険率 $5 \%$ と設定した。

結 果

全受診者 48,454 名のうち，新たに診断された腎がん， 膀胱がんおよび前立腺がんは，それぞれ 45,47 および 215 例であり，その罹患率は，それぞれ 0.093, 0.097 およ び $0.721 \%$ であった. 全受診者および各泌尿器がんの背景 を表 1 に示す.

腎がんの罹患についての検討を示す，単変量解析で腎 がんの罹患と有意な相関を認めた因子は, 男性, 高齢者, 飲酒, BMI, 20 歳時より体重が $10 \mathrm{~kg}$ 以上増加扔よび高血 圧であった。これらの因子の中で, 多変量解析にて高齢 者のみが腎がんの䍜患と独立した相関を示した（表 2).

膀胱がんの罹患に関する検討では，単変量解析で有意 な相関を認めた因子は男性, 高齢者, 総喫煙年数および 飲酒であった，多変量解析にて，男性抒よび高龄者が膀 胱がんの罹患と独立した相関を有した（表 3).

前立腺がんの罹患についての検討では, 単変量解析で 有意に相関した因子は, 高齢者, 総喫煙年数, 20 歳時よ り体重が $10 \mathrm{~kg}$ 以上増加，ストレスの蓄積掞よび脂質異 常症であった. 多変量解析では高齢者および脂質異常症 が前立腺がんの罹患と独立した相関を示した（表 4）.

\section{考察}

2015 年の腎および尿路（膀胱は除く）を含めたがんの 集計において, 年齢階級別罹患率 ${ }^{1)}$ は高齢者ほど上昇し, 男女とも 80〜84 歳代でピークを示している. 今回の結果 からもドック受診者層に比べ，腎がん罹患症例の年齢は 顕著に高かった. また, Samuel $ら^{2)}$ は飲酒無し群に比べ, 毎日アルコールを約 $30 \mathrm{~g}$ 摂取すると腎がんのリスクが 最も減少するが, それ以上飲酒してもリスク減少にはつ ながらない,つまり J-shape の関係があると述べている. 今回飲酒量の定量的評価は行っていないが, 単変量解析 
表 2 腎がんの結果

\begin{tabular}{|c|c|c|c|c|}
\hline & \multicolumn{2}{|c|}{$\begin{array}{c}\text { 単変量解析 } \\
\text { (ロジティッ回帰分析) }\end{array}$} & \multicolumn{2}{|c|}{$\begin{array}{c}\text { 多変量解析 } \\
\text { (ロジステイック回帰分析) }\end{array}$} \\
\hline & 95\% 信頼区間 & P 值 & 95\% 信頼区間 & $\mathrm{P}$ 值 \\
\hline 性別 男性/女性 & $1.070-4.611$ & 0.032 & $0.590-2.825$ & 0.523 \\
\hline 年歯令 ～～～～～～ & $1.036-1.096$ & $<0.001$ & $1.038-1.105$ & $<0.001$ \\
\hline 総喫煙年数 & $0.995-1.035$ & 0.159 & & \\
\hline 飲酒 & $1.356-4.687$ & 0.004 & $0.947-3.973$ & 0.070 \\
\hline $\mathrm{BMI}$ & $1.030-1.207$ & 0.007 & $0.981-1.211$ & 0.110 \\
\hline $\begin{array}{l}20 \text { 歳時より体重が } \\
10 \mathrm{~kg} \text { 以上増加 }\end{array}$ & $1.004-5.037$ & 0.049 & $0.742-4.304$ & 0.195 \\
\hline ストレスの蓄積 & $0.572-1.886$ & 0.901 & & \\
\hline 十分な睡眠 & $0.402-1.506$ & 0.456 & & \\
\hline 十分な乳製品摂取 & $0.529-1.728$ & 0.881 & & \\
\hline 高血圧 & $1.351-4.455$ & 0.003 & $0.666-2.391$ & 0.475 \\
\hline 糖尿病 & $0.464-3.622$ & 0.620 & & \\
\hline 脂質異常症 & $0.719-2.321$ & 0.392 & & \\
\hline
\end{tabular}

表 3 膀胱がんの結果

\begin{tabular}{|c|c|c|c|c|}
\hline & \multicolumn{2}{|c|}{$\begin{array}{c}\text { 単変量解析 } \\
\text { (ロジス田分析) }\end{array}$} & \multicolumn{2}{|c|}{$\begin{array}{c}\text { 多変量解析 } \\
\text { (ロジスデ州分析) }\end{array}$} \\
\hline & 95\% 信頼区間 & $\mathrm{P}$ 值 & 95\% 信頼区間 & $\mathrm{P}$ 值 \\
\hline 性別 男性/女性 & $2.385-18.513$ & $<0.001$ & $1.527-14.441$ & 0.007 \\
\hline 年齢 & $1.033-1.091$ & $<0.001$ & $1.029-1.090$ & $<0.001$ \\
\hline 総喫煙年数 & $1.018-1.056$ & $<0.001$ & $0.989-1.028$ & 0.414 \\
\hline 飲酒 & $1.175-4.222$ & 0.014 & $0.724-2.774$ & 0.308 \\
\hline BMI & $0.991-1.170$ & 0.082 & & \\
\hline $\begin{array}{l}20 \text { 歳時より体重が } \\
10 \mathrm{~kg} \text { 以上増加 }\end{array}$ & $0.438-1.466$ & 0.473 & & \\
\hline ストレスの蓄積 & $0.486-1.60$ & 0.680 & & \\
\hline 十分な睡眠 & $0.380-1.413$ & 0.353 & & \\
\hline 十分な乳製品摂取 & $0.771-2.421$ & 0.286 & & \\
\hline 高血圧 & $0.742-2.665$ & 0.296 & & \\
\hline 糖尿病 & $0.856-4.758$ & 0.108 & & \\
\hline 脂質異常症 & $0.788-2.489$ & 0.252 & & \\
\hline
\end{tabular}

表 4 前立腺がんの結果

\begin{tabular}{|c|c|c|c|c|}
\hline & \multicolumn{2}{|c|}{$\begin{array}{c}\text { 単変量解析 } \\
\text { (ロジステイック回帰分析) }\end{array}$} & \multicolumn{2}{|c|}{$\begin{array}{c}\text { 多変量解析 } \\
\text { (ロジステイック回帰分析) }\end{array}$} \\
\hline & 95\% 信頼区間 & $\mathrm{P}$ 值 & 95\% 信頼区間 & $\mathrm{P}$ 值 \\
\hline 年齢 & $1.136-1.170$ & $<0.001$ & $1.139-1.175$ & $<0.001$ \\
\hline 総喫煙年数 & $1.007-1.026$ & $<0.001$ & $0.990-1.006$ & 0.594 \\
\hline 飲酒 & $0.748-1.349$ & 0.976 & & \\
\hline BMI & $0.917-1.008$ & 0.104 & & \\
\hline $\begin{array}{l}20 \text { 歳時より体重が } \\
10 \mathrm{~kg} \text { 以上増加 }\end{array}$ & $0.502-0.894$ & 0.006 & $0.840-1.557$ & 0.396 \\
\hline ストレスの蓄積 & $0.386-0.722$ & $<0.001$ & $0.816-1.564$ & 0.462 \\
\hline 十分な睡眠 & $0.544-1.023$ & 0.069 & & \\
\hline 十分な乳製品摂取 & $0.673-1.154$ & 0.357 & & \\
\hline 高血圧 ～～～～～ & $0.987-1.770$ & 0.061 & & \\
\hline 糖尿病 & $0.722-1.782$ & 0.586 & & \\
\hline 脂質異常症 & $1.041-1.80$ & 0.024 & $1.016-1.790$ & 0.039 \\
\hline
\end{tabular}

で飲酒と腎がんの罹患は有意に相関した。したがって， 適度の飲酒に腎がんのリスク減少効果はあっても, 多量 の飲酒は逆にリスクを増加させる可能性が示唆されたと
考えられる. 一方, BMI に関しても今回の検討では単変 量解析で腎がんの罹患と有意な相関を認めたが, Furan らも ${ }^{3)}$ ，腎がん罹患の相対リスク比は， $\mathrm{BMI}<25 \mathrm{~kg} / \mathrm{m}^{2}$ 
と比較して， $25 \mathrm{~kg} / \mathrm{m}^{2} \leqq \mathrm{BMI}<30 \mathrm{~kg} / \mathrm{m}^{2}$ では $1.28(95 \%$ CI : $1.24 \sim 1.33), \quad \mathrm{BMI} \geqq 30 \mathrm{~kg} / \mathrm{m}^{2}$ では $1.77 （ 95 \% \mathrm{CI}$ ： 1.68〜1.87) と, BMI が高いほど腎がんの罹患が増加する と報告している。腎がんと肥満の相関に関しては, BMI の上昇により free insulin-like growth factor 1 が上昇す ることにより, 腎がん細胞の増殖が刺激されアポトーシ スが抑制されることによるとの興味深い報告もある ${ }^{45)}$. 高血圧に関しても単変量解析にて腎がんの罹患と有意な 相関を認めたが, Steffen ${ }^{6}$ らも収縮期血圧 $(\geqq 160 \mathrm{mmHg}$ vs $<120 \mathrm{mmHg}$ ) および拡張期血圧 $(\geqq 100 \mathrm{mmHg}$ vs $<80$ $\mathrm{mmHg}$ )で検討を行い，腎がん罹患の相対危険度はそれ ぞれ 2.48 および 2.34 であり, 高血圧は独立した危険因子 であると述べている.高血圧㧍よび肥満を有していると, 脂質過酸化と活性酸素が過剩に生成され腎の発がんが促 進されるとの基礎的な研究結果 ${ }^{7) 99}$ も報告されている.

今回の解析に扔いては, 膀胱がん罹患症例の $91.5 \%$ を

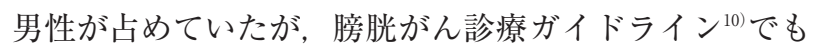
男性は女性の約 4 倍高頻度に罹患するとされている。 2015 年の膀胱がんの集計において年齢階級別罹患率 ${ }^{11}$ みると, 男女ともに 40 歳未満の若年者では極めて低く, 40 歳代から徐々に増加し，高齢化する程高值であった。 今回の検討でも膀胱がん罹患症例は顕著に高齢であっ た。哭煙に関しては, 単変量解析で膀胱がんの罹患と有 意な相関を認めたが, 多変量解析では独立した影響を認 めなかった。 しかし, 膀胱がんの最大の危険因子が喫煙 であることは先行研究からも周知のことであり, 膀胱が ん診療ガイドラインでも喫煙者は, 非契煙者に比べ $2 \sim 5$ 倍発症リスクを高めること, また夕バコ関連の発がん物 質として 60 種類以上の物質が指摘されており, 特に amino-biphenyl などを含む arylamines や活性酸素種が 膀胱がんの発生に重要であると述べられている. 今回の 解析結果は，喫煙本数が考慮されておらず，2006〜2007 年以後の喫煙状況が検討されていないことの影響による 可能性もあると考えられる。飲酒に関してZaitsu ら ${ }^{11}$ は, 739 名の膀胱がん症例と 7,196 名のコントロールを比 較した結果, 日本人に押いては 1 日 $15 \mathrm{~g}$ 以上のアルコー 儿摂取が膀胱がんの独立した危険因子となり，飲酒歴の ある者は非飲酒者と比べ $1.3 \sim 1.4$ 倍膀胱癌のリスクがあ ると報告している. 我々の検討でも単変量解析では飲酒 と膀胱がん䍜患リスクが有意に相関しており, 飲酒は膀 胱がんのリスク因子である可能性が示唆されている.

前立腺がんが, 高齢者に好発することは周知の通りで あり, 2015 年の前立腺がんの集計においても年齢調整罹 患率 ${ }^{1}$ では 45 歳以降で増加し始め, 60 歳以降で急峻とな り 70〜74 歳がピークとなることが示されていた. 今回の 検討でも前立腺がん罹患例は顕著に高龄であった．また 脂質異常について, Kristine ${ }^{12)}$ らは高コレステロール血症 により，腫瘍内ステロイド合成（アンドロゲン合成）の 活性化, 炎症, 細胞增殖, 細胞膜に扔ける脂質ラフトの 変化などを引き起こし, 進行性前立腺がんのリスクを上
げると述べている．また Hayashi ${ }^{133}$ は高 TG 血症を有 すると, 特に 60 歳以上で前立腺がんの発生率が高いと報 告している。原因として高 TG 值が誘因となる慢性ス卜 レスが 2 次的あるいは散発性の前立腺がん発生に寄与し ているとの報告を認めるが，一定の見解を得るには至っ ていない(1415)。 また Jespersen ら ${ }^{16)}$ は, スタチン使用によ り前立腺がん罹患リスクを $6 \%$ 低下させ，特に進行がん は 10\% 低下させたと報告している.今回の我々の検討で も, 脂質異常症は前立腺がん罹患に独立した影響を有し ており, 前立腺がんに対し何らかの促進作用があること が示唆される. 今後は脂質の種類およびスタチンの内服 の有無なども考慮した総合的な検討が必要であると考え られる。

一般的に高齢になるにつれ，任意型の人間ドックょり 対策型の住民健診を受ける傾向がある，ただし住民健診 の項目では泌尿器がんを診断するには不十分であり, 進 行がんとなり自覚症状が出現して診断されることも多 い. 当センター人間ドックでは PSA, 尿検査, エコーに よる腎のチェックに加え，尿を貯めた状態で膀胱の チェックもしており, 早期がんで診断されることが多い. 当然低侵襲の治療で根治できるケースが多く, 泌尿器が んの罹患の多い高齢者の人間ドック受診率を向上させる ことは必要である。また今回の検討で前立腺がんと脂質 異常症の有意な相関を認めたが, 今後健診の現場で, 脂 質異常症を有する男性受診者に対する生活指導の内容 に, 脂質代謝の改善により将来の前立腺がんの罹患リス クを下げる可能性があることも加えることにより，生活 習慣改善の動機付けの強化につなげることは有益と思わ れる。

\section{結語}

2006〜2008 年に人間ドックを受診した症例を対象と し, 泌尿器がんの罹患に焦点を当てた比較的長期間の観 察研究を施行した。本研究に打ける腎がん, 膀胱がんお よび前立腺がんの罹患率はそれぞれ 0.093, 0.097, および 0.721\%であった．また，泌尿器がんの罹患と相関を有す るリスク因子は，その種類により様々であったが，高齢 者はいずれの泌尿器がんにおいても共通してその罹患と 独立した相関を示した.

文

1）国立がん研究センターがん情報サービス「がん登 録・統計」.

2) Antwi Samuel O., Eckel-Passow Jeanette E., Diehl Nancy D., Serie Daniel J., Custer Kaitlynn M., Wu Kevin J., Cheville John C., Thiel David D., Leibovich Bradley C. and Parker Alexander S.: Alcohol consumption, variability in alcohol dehydrogenase genes and risk of renal cell cartinoma. Int J Cancer, 142(4), 747-756, 2018. 
3) Furan Wang and Yinghua Xu: Body mass index and risk of renal cell cancer:A dose-response metaanalysis of published cohort studies. Int J Cancer, 135(7), 1673-1686, 2014.

4) Frystyk J, Vestbo E, Skjaerbaek C, Mogensen CE and Orskov H: Free insulin-like growth factors in human obesity. Metabolism, 44, 37—44, 1995.

5) Kellerer M, Eye Corleta H, Mühlhöfer A, Capp E, Mosthaf L, Bock S, Petrides PE and Häring HU: Insulin-and insulin-like growth-factor-1 receptor tyrosine-kinase activities in human renal cartinoma. Int J Cancer, 62, 501—507, 1995.

6) Steffen W, Heiner B, Tobias P, Cornelia W, Anja O, Anne T, Kim O, Nikolaus B, Jakob L, Antonia T, Theodore M, Dimitrios T, Sabina S, Domenico P, Paolo V, Salvatore P, Petra HMP, H Bas B, WM Monique V, Borje L, Goran H, Goran B, Carlos AG, Miren D, Aurelio B, MJ Tormo, Naomi A, Andrew R, Sheila B, Kay-Tee K, Sabina R, Pietro F, Teresa N and Elio R: Blood Pressure and Risk of Renal Cell Cartinoma in the European Prospective Investigation into Cancer and Nutrition. Am J Epidemiol, 167, 438-446, 2008.

7) Gago-Dominguez M, Castelao JE, Yuan JM, Ross RK and Yu MC: Lipid peroxidation: a novel and unifying concept of the etiology of renal cell cartinoma (United States). Cancer Causes Control, 13, 287293, 2002.

8) Toyokuni S, Luo XP, Tanaka T, Uchida K, Hiai H and Lehotay DC: Induction of a wide range of $\mathrm{C}_{2-12}$ aldehydes and $\mathrm{C}_{7-12}$ acyloins in the kidney of Wistar rats after treatment with a renal cartinogen, ferric nitrilotriacetate. Free Radic Biol Med, 22, 10191027, 1997.
9) Toyokuni S, Uchida K, Okamoto K, HattoriNakakuki Y, Hiai H and Stadtman ER: Formation of 4-hydroxy-2-nonenal-modified proteins in the renal proximal tubules of rats treated with a renal carcinogen, ferric nitrilotriacetate. Proc Nat Acad Sci USA, 91, 2616-2620, 1994.

10）日本泌尿器科学会：膀胱癌診療ガイドライン 2015 , 医学図書出版, 2015.

11) Zaitsu M, Nakamura F, Toyokawa S, Tonooka A, Takeuchi T, Homma Y and Kobayashi Y: Risk of Alcohol Consumption in Bladder Cancer: Case-Control Study from a Nationwide Impatient Database in Japan. The Tohoku Journal of Experimental Medicine, 239(1), 9-15, 2016.

12) Kristine P, Michael RF and Keith RS: Cholesterol and Prostate Cancer. Curr Opin Pharmacol, 12(6), 751-759, 2012.

13) Hayashi N, Matsushima M, Yamamoto T, Sasaki H, Takahashi $\mathrm{H}$ and Egawa S: The impact of hypertriglyceridemia on prostate cancer development in patients aged $\geqq 60$ years. BJU Int, 109, 515—519, 2012.

14) YuPeng L, Yuxue Z, PengFei L, Cheng C, YaShuang Z, DaPeng L and Chen D: Cholesterol Levels in Blood and the Risk of Prostate Cancer: A Metaanalysis of 14 Prospective Studies. Cancer Epidemiol Biomarkers Prev, 24(7), 1086-1093, 2015.

15) Ma HQ, Cui LH, Li CC, Yu Z and Piao J: Effects of Serum Triglycerides on Prostate Cancer and Breast Cancer Risk: A Meta-Analysis of Prospective Studies. Nutr Cancer, 68(7), 1073-1082, 2016.

16) Jespersen $C G$, Nørgaad $M$, Friis $S$, Skriver $C$ and Borre M: Statin use and risk of prostate cancer: a Danish population-based case-control study, 19972010. Cancer Epidemiol, 38(1), 42—47, 2014. 


\title{
EXAMINATION OF THE INCIDENCE AND RISK FACTORS ABOUT URINARY CANCERS (RENAL, BLADDER, AND PROSTATE) IN EXAMINEES OF HEALTH SCREENING
}

\author{
Syunsuke Nobata ${ }^{1 / 3)}$, Syoutarou Kiuchi ${ }^{1)}$, Megumi Watanabe ${ }^{1)}$, Atsuyoshi Mori ${ }^{11}$, Sigeki Mutou' and Hideaki Miyake ${ }^{2)}$ \\ ${ }^{1)}$ Seirei Preventive Health Care Center \\ ${ }^{2}$ Seirei Center for Health Promotion and Preventive Medicine \\ ${ }^{3)}$ Department of Urology Hamamatsu University School of Medicine
}

\begin{abstract}
:
(Objective) We studies morbidity and risk factors related to urinary cancers (renal, bladder, and prostate) from health screening interviews and results.

(Subjects and Methods) We extracted data from 48,454 adults who underwent health screenings between April 2006 and March 2008.

Of particular interest were examinees who were newly diagnosed with urinary cancer after the consultation. The data examined included factors such as sex, age, total years of smoking, body mass index (BMI), drinking status, weight gain ( $>10 \mathrm{~kg}$ from the age of 20 ), accumulation of stress, sleep condition/habits, adequate dairy product intake, hypertension, diabetes mellitus, and dyslipidemia.

(Results) The numbers of patients who were diagnosed with renal, bladder, or prostatic cancer were 45, 47, and 215, respectively. The corresponding morbidity rates were $0.093 \%, 0.097 \%$, and $0.721 \%$. From the results of the univariate analysis, renal cancer was found to be significantly correlated with the male gender, old age, high BMI, drinking, weight gain, and hypertension. In addition, we found a significant correlation between bladder cancer and male gender, old age, total years of smoking, and drinking. Prostate cancer was significantly correlated with old age, total years of smoking, weight gain, accumulation of stress, and dyslipidemia. The multivariate analysis demonstrated a significant correlation between renal cancer and old age, between bladder cancer and both male gender and old age, and between prostatic cancer and both old age and dyslipidemia.

(Conclusion) Old age was identified as a common risk factor that is significantly and independently correlated with urinary cancers.
\end{abstract}

(Jpn. J. Urol 111(4): 114-119, 2020)

Keywords: health screening, risk factor, urinary cancer

Received: April 19, 2020, Accepted: May 26, 2020

(C) 2020 The Japanese Urological Association 